Case report

\title{
FIRST CONFIRMED CLINICAL CASE OF ANAPLASMA PLATYS IN A DOG IN SERBIA
}

\author{
ILIĆ BOŽOVIĆ Anja ${ }^{1}$, RADAKOVIĆ Milena ${ }^{1}$, SPARIOSU Kristina ${ }^{1}$, \\ TYRRELL Phyllis ${ }^{2}$, CHANDRASHEKAR Ramaswamy ${ }^{2}$, MIŠIĆ Dušan ${ }^{1,3 *}$, \\ KOVAČEVIĆ FILIPOVIĆ Milica ${ }^{1}$
}

${ }^{1}$ Faculty of Veterinary Medicine, University of Belgrade, Bulevar oslobođenja 18, Belgrade 11000, Serbia;
${ }^{2}$ IDEXX Laboratories Inc., Westbrook, ME, USA; ${ }^{3}$ Faculty of Biotechnology and Food Science,
Wroclaw University of Environmental and Life Sciences, 37 Chełmońskiego Str., 51-630 Wrocław,
Poland

(Received 04 November 2020, Accepted 10 February 2021)

In September 2018, a four-month-old dog with fever and petechial bleeding came to the internal clinic at the Faculty of Veterinary Medicine University of Belgrade. On hematology analysis, thrombocytopenia and mild anemia were observed. Examination of the blood smear revealed platelet inclusions. The commercial serology test was positive for Anaplasma spp. The dog was treated with doxycycline for 14 days, and after 48 hours from the beginning of the treatment, the symptoms subsided. PCR analysis and sequencing confirmed infection with $A$. platys.

Keywords Anaplasma platys, dog, Serbia, PCR, serology

\section{INTRODUCTION}

Anaplasma (A.) platys is a causative agent of cyclic canine thrombocytopenia (thrombocytotropic anaplasmosis). The disease is geographically distributed on all continents and is potentially zoonotic [1]. It is considered that the vector is Rhipicephalus sanguineus, although, $A$. platys DNA has also been found in other tick species without the proof of possible transmission. The only clinical sign of $A$. platys infection in dogs may be severe thrombocytopenia when $A$. platys inclusions (morulae) can be seen in blood smears. Dogs are mostly asymptomatic, but if symptoms do occur, then pale mucous membranes, fever, petechial hemorrhage, uveitis, and lymphadenopathy could be observed. In the first 15-21 days of infection, thrombocytopenia occurs during which the platelet count may fall below $20 \times 10^{9} / \mathrm{L}$. After this phase, the platelet count temporarily returns to normal. This recurs cyclically. In the later stages of the disease, it is increasingly difficult to find A.platys in blood smears [2]. The immune response to $A$. platys with specific immunoglobulins can be detected by IFA

*Corresponding author: e-mail: dusan.misic@upwr.edu.pl 
and ELISA. The distinction between $A$. phagocytophilum and A. platys is possible by molecular methods and by a proprietary, research prototype ELISA SNAP® test (SNAP M-A test) (IDEXX Laboratories, Inc., USA)[3].

Several seroprevalence studies in Serbia have so far found that outdoor dogs were highly exposed to members of the Anaplasmataceae family with a detected prevalence of $20-30 \%$ [4-6]. However, A. platys has not yet been isolated from dogs on Serbian territory.

\section{CASE PRESENTATION}

The four-month-old Rottweiler male was brought to the internal clinic at the Faculty of Veterinary Medicine, University of Belgrade, Serbia, in September 2018. The anamnesis described that the dog was depressed for more than 2 weeks. The dog reportedly was regularly vaccinated and treated with an unknown ectoparasiticide after a tick was spotted on it. The dog had a good appetite, but physical examination revealed fever $\left(39.6^{\circ} \mathrm{C}\right)$ and petechial bleeding on the abdomen and buccal mucosa. The dog had been normally hydrated and eupnoeic. A blood sample was taken from the cephalic vein in a vacutainer with EDTA (Becton Dickinson, USA) at the day of admission (day 1), and was taken 2 more times; once on Day 7 and then again on Day 30, the last day of treatment. Romanowsky-stained blood smear Day 1) identified A. platys morulae in giant platelets (Figure 1). Complete blood count (CBC) done immediately upon blood collection revealed moderate normocytic normochromic anemia and severe thrombocytopenia, with a manual count of $12 \times 10^{9}$ platelets $/ \mathrm{L}$ (Table 1).

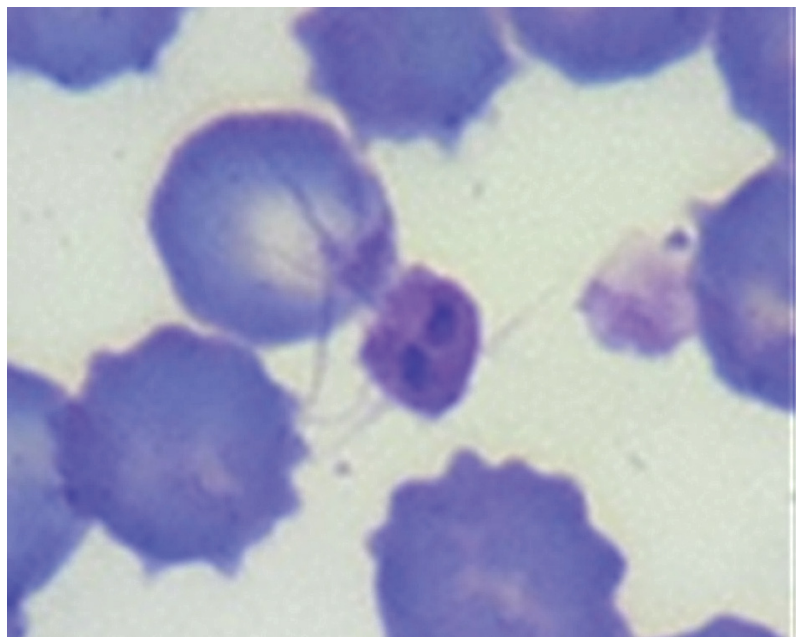

Figure 1. A. platys morulae in the macroplatelates, Romanowsky-stained blood smear (100x). 
Table 1. Complete blood count of the infected dog, on the presentation (Day 1), during treatment (Day 7), and at the end of therapy (Day 30).

\begin{tabular}{lcccc}
\hline Parameter* & Day $\mathbf{1}$ & Day 7 & Day 30 & Reference interval \\
\hline WBC $\left(\times 10^{9} / \mathrm{L}\right)$ & 8.6 & 24.4 & 17.92 & $6.0-17.0$ \\
\hline RBC $\left(\times 10^{12} / \mathrm{L}\right)$ & 3.81 & 4.98 & 4.90 & $5.5-8.5$ \\
HGB $(\mathrm{g} / \mathrm{L})$ & 87 & 119 & 126 & $120-180$ \\
\hline HCT $(\%)$ & 26.2 & 34.2 & 31.3 & $37.0-55.0$ \\
MCV $(\mathrm{fL})$ & 68.8 & 68.7 & 64 & $60.0-77.0$ \\
\hline MCH $(\mathrm{pg})$ & 22.8 & 23.9 & 25.7 & $19.5-24.5$ \\
MCHC $(\mathrm{g} / \mathrm{L})$ & 332 & 348 & 403 & $320-360$ \\
\hline PLT $\left(\times 10^{9} / \mathrm{L}\right)$ & $<20$ & 368 & 412 & $200-500$ \\
PLT $\left(\times 10^{9} / \mathrm{L}\right)$ manual & 12 & n.a. & n.a. & $200-500$ \\
\hline Ly $(\%)$ & 19.2 & 7.1 & 25.7 & $12.0-30.0$ \\
Mo $(\%)$ & 3.3 & 0 & 6 & $3.0-10.0$ \\
\hline Eos $(\%)$ & 13.9 & 0 & 0 & $0.0-10.0$ \\
Gr $(\%)$ & 63.6 & 92.9 & 68.2 & $60.0-80.0$ \\
\hline
\end{tabular}

*Analysis has been performed on Abacus Junior Vet hematology analyzer (Diatron, Austria). Note that analyzer erroneously did not detect platelets, while manual counting revealed presence of their low number.

DNA for PCR and sequencing was isolated from the whole blood sample using the High Pure PCR Template Kit (Roche Diagnostics, Germany). Two targets were amplified. A. platys outer membrane protein p44 (IDEXX R\&D assay, IDEXX Laboratories, USA) with primer set: P44 FP 5'-CCGGCGTTTAGTAAGATAAATG-3' and P44 RP 5'-GCAAATTTAACGATCTCCGCC-3', (TIB MOLBIOL, Germany). Amplicons were ligated into TOPO TA vector plasmid pCR2.1 (TOPO TA Cloning Kit, Invitrogen, Thermo Fisher, USA). Plasmids were transformed into TOP10 cells (Invitrogen, Thermo Fisher, USA) which were spread onto LB agar (Millipore Sigma, USA) with $50 \mu \mathrm{g} / \mathrm{ml}$ kanamycin (Millipore Sigma, USA). Colonies were transferred to LB broth (Teknova, USA) with $50 \mu \mathrm{g} / \mathrm{ml}$ kanamycin and incubated $16-20$ hours at $37^{\circ} \mathrm{C}$. Plasmids were isolated using the High Pure Plasmid Isolation Kit (Roche Diagnostics, Germany). The second target was $A$. platys $16 \mathrm{~S}$ ribosomal RNA (with primer set PLATYS 5'-GATTTTTGTCGTAGCTTGCTATG-3' and EHR16SR 5'-TAGCACTCATCGTTTACAGC-3', Invitrogen, Thermo Fisher, USA).

DNA Sequencing was done at the University of Delaware DNA Sequencing and Genotyping Center (Newark, Delaware, USA). Sequences were analyzed with Lasergene software (DNASTAR, Madison, Wisconsin, USA). A search in the EzBioCloud Database revealed that $16 \mathrm{~S}$ rRNA sequences with $>95 \%$ similarities belonged to the genus Anaplasma. The genomic sequences of outer membrane protein $\mathrm{p} 44$ showed $100 \%$ identity to all analogous $A$. platys sequences in the database. The SNAP $4 \mathrm{Dx} \circledast$ 
test (IDEXX Laboratories, Inc., USA) was positive for antibodies against Anaplasma spp $[7,8]$. Retrospectively, the SNAP M-A test, which offers additional species specificity, detected specific $A$. platys antibodies in the serum specimen taken on the day of admission. ELISA SNAP M-A (IDEXX Laboratories, Inc., USA) excluded co-infections with Borrelia spp., Ehrlichia spp. and Dirofilaria spp. The dog was treated with doxycycline ( $2 \mathrm{mg} / \mathrm{kg}$ IM every 24 hours) for 2 weeks. Symptoms of infection resolved completely after 48 hours, and the platelet count increased to normal within 7 days. The SNAP M-A test revealed that the $\operatorname{dog}$ was seroreactive against $A$. platys and seronegative against $A$. phagocytophylum on presentation, and seronegative against both pathogens on Day 30. The tick was not found on the dog at the time of the examination and thus, the species of the tick could not be confirmed.

The finding of $A$. platys is not surprising given that it was clear from serological surveys that members of the Anaplasma genus are present amongst the dogs on the territory of Serbia.

The dogs infected in the USA with $A$. platys are usually asymptomatic, while it appears that those infected in southern Europe most often develop distinct clinical abnormalities [2,9]. Coinfections with other vector-borne pathogens also influence the severity of disease [2,9]. Nonetheless, young dogs, like the one in our presentation, and dogs surviving stressful conditions, appear more susceptible to developing the clinical disease [10-13]. The dog in this case probably had an underdeveloped immune system and was under stressful conditions related to the change of the owner and consecutive travel. In conclusion, because of the high seroprevalence in dogs suggesting that there is an increased likelihood of exposure and infection with a potentially zoonotic pathogen[14,15], more attention should be given to the diagnosis of anaplasmosis in both human and veterinary medicine in Serbia.

\section{Acknowledgment}

The study was supported by the Serbian Ministry for Science and Technology grants \# 175061 and IDEXX Laboratories, Inc., Westbrook, Maine, USA.

The authors would like to thank Una Popović Lipovac for her contribution to laboratory work, and colleague Ivana Pantelić for carefully taking care of the patient.

\section{Authors' contributions}

AIL, MR, KS, PT, RC, MKF, DM carried out the molecular genetic studies, participated in the sequence alignment and drafted the manuscript. PT, RC, MKF carried out the immunoassays. PT, RC participated in the sequence alignment. MKF participated in the design of the study and performed the statistical analysis. AIB, MKF, MR, KS conceived of the study, and participated in its design and coordination and helped to draft the manuscript. All authors read and approved the final manuscript. 


\section{Declaration of conflicting interests}

The author(s) declared no potential conflicts of interest with respect to the research, authorship, and/or publication of this article. Phyllis Tyrell and Ramaswamy Chandrashekar are employees of IDEXX Laboratories, Inc.

\section{REFERENCES}

1. Maggi RG, Mascarelli PE, Havenga LN, Naidoo V, Breitschwerdt EB: Co-infection with Anaplasma platys, Bartonella benselae and Candidatus Mycoplasma haematoparvum in a veterinarian. Parasit Vectors 2013,6:103.

2. Sykes JE, Foley JE, Anaplasmosis, In: Canine and Feline Infectious Diseases, Elsevier Inc., 2013: pp. 290-299.

3. Hegarty BC, Qurollo BA, Thomas B, Park K, Chandrashekar R, Beall MJ, Thatcher B, Breitschwerdt EB: Serological and molecular analysis of feline vector-borne anaplasmosis and ehrlichiosis using species-specific peptides and PCR. Parasit Vectors 2015, 8:320.

4. Spasojevic-Kosic L, Savic S, Potkonjak A, Vracar V: Retrospective analysis of clinical and laboratory findings in hunting dogs with serologic reactions to tick-borne pathogens (Anaplasma phagocytophilum, Borrelia burgdorferi, Babesia canis, Ehrlichia canis, Ricketsia conorii). Veterinarski Glasnik 2015, 69:219-232.

5. Kovačević Filipović MM, Beletić AD, Ilić Božović AV, Milanović Z, Tyrrell P, Buch J, Breitschwerdt EB, Birkenheuer AJ, Chandrashekar R: Molecular and serological prevalence of Anaplasma phagocytophilum, A. platys, Ehrlichia canis, E. chaffeenses, E. ewingii, Borrelia burgdorferi, Babesia canis, B. gibsoni and B. vogeli among clinically healthy outdoor dogs in Serbia. Vet Parasitol Reg Stud Reports 2018, 14:117-122.

6. Potkonjak A, Vračar V, Savić S, Lako B, Radosavljević V, Cincović M, Suvajdžić L, Jurišić A, Petrović A: The seroprevalence of Anaplasma phagocytophilum infection in dogs in the Autonomous Province of Vojvodina, Serbia. Veterinarski Arhiv 2015, 85:385-394.

7. Ferreira RF, Cerqueira Ade M, Pereira AM, Velho PB, Azevedo RR, Rodrigues IL, Almosny NR: Cross-reaction evaluation of PCR-Anaplasma platys positive dogs tested to Anaplasma phagocytophilum antibodies by commercial ELISA. Rev Bras Parasitol Vet 2008, 17 (Suppl 1):5-8.

8. Lasta CS, dos Santos AP, Messick JB, Oliveira ST, Biondo AW, Vieira RF, Dalmolin ML, González FH: Molecular detection of Ehrlichia canis and Anaplasma platys in dogs in Southern Brazil. Rev Bras Parasitol Vet 2013, 22(3):360-366.

9. Gaunt S, Beall M, Stillman B, Lorentzen L, Diniz P, Chandrashekar R, Breitschwerdt E: Experimental infection and co-infection of dogs with Anaplasma platys and Ehrlichia canis: hematologic, serologic and molecular findings. Parasit Vectors 2010, 3(1):33.

10. Harrus S, Aroch I, Lavy E, Bark H: Clinical manifestations of infectious canine cyclic thrombocytopenia. Vet Rec 1997, 141(10):247-250.

11. de Caprariis D, Dantas-Torres F, Capelli G, Mencke N, Stanneck D, Breitschwerdt EB, Otranto D: Evolution of clinical, haematological and biochemical findings in young dogs naturally infected by vector-borne pathogens. Vet Microbiol 2011, 149(1-2):206-212. 
12. De Tommasi AS, Baneth G, Breitschwerdt EB, Stanneck D, Dantas-Torres F, Otranto D, de Caprariis D: Anaplasma platys in bone marrow megakaryocytes of young dogs. J Clin Microbiol 2014, 52(6):2231-2234.

13. Dyachenko V, Pantchev N, Balzer HJ, Meyersen A, Straubinger RK: First case of Anaplasma platys infection in a dog from Croatia. Parasit Vectors 2012, 5:49.

14. Potkonjak A, Žekić Stošić M: Tick-borne infections of dogs in Serbia: a review of research. Veterinarski Glasnik 2020, 74:107-124.

15. Potkonjak A, Savić S, Spasojević Kosić Lj, Tasić Otašević S, Tomanović S, Kovačević Filipović M: Consensus statement on the epidemiological situation and expected frequency of canine vector-borne diseases in Serbia. Veterinarski Glasnik 2020, 74:211-215.

\title{
PRVI POTVRĐENI KLINIČKI SLUČAJ INFEKCIJE PSA VRSTOM ANAPLASMA PLATYS U SRBIJI
}

\author{
ILIĆ BOŽOVIĆ Anja, RADAKOVIĆ Milena, SPARIOSU Kristina, \\ TYRRELL Phyllis, CHANDRASHEKAR Ramaswamy, MIŠIĆ Dušan, \\ KOVAČEVIĆ FILIPOVIĆ Milica
}

U septembru 2018. godine, štene staro četiri meseca, sa znacima groznice i petehijalnim krvarenjem, je došlo u ambulantu Klinike za male životinje Fakulteta veterinarske medicine Univerziteta u Beogradu. Hematološka analiza je pokazala trombocitopeniju i blagu anemiju. Pregledom krvnog razmaza ustanovljene su inkluzije u trombocitima. Komercijalni serološki test je pokazao prisustvo antitela protiv Anaplasma spp. Sprovedena je terapija doksiciklinom u trajanju od 14 dana, a posle 48 sati od početka terapije znaci bolesti su se povukli. PCR analizom i senkvencioniranjem je potvrđeno prisustvo Anaplasma platys. 